\title{
WHATEVER HAPPENED TO BRAZIL?
}

\author{
LADISLAU DOWBOR ${ }^{1}$ \\ ${ }^{1}$ Pontifical Catholic University of São Paulo, R. Min. de Godoy 969, CEP 05015-001, São Paulo, Brazil. \\ ORCID: 0000-0002-0465-6483, Email: 1dowbor@gmail.com
}

ABSTRACT: Under Luiz Inácio Lula da Silva and Dilma Rousseff, during the 2003-2013 decade that the World Bank called "the Golden Decade of Brazil", we had simultaneously economic growth, social inclusion, environmental protection and job expansion. With no deficit and very low inflation, and all despite the turbulence of the 2008 crisis. The onslaught on inclusive policies started in 2014. Dilma was ousted through a thinly disguised coup in 2016, and ex-president Lula was jailed for the time of the 2018 election, won by Jair Bolsonaro. Since the old oligarchies and corporate interests took over, the economy is stalled, unemployment has doubled, the Amazon is being cut down, child mortality is growing. The pandemic deepened an already general economic and social crisis. This paper aims to present an overview of what went wrong, centring not on the pandemic itself but on the deeper structural change that reversed the inclusive growth model of the popular governments. This involves the economy but also technological, social and political change. The overall thesis is that inclusive development works, austerity does not.

KEYWORDS: Brazil, financialization, inequality, crisis, lawfare 
One of man's oldest exercises in moral philosophy is the search for a superior moral justification for selfishness. (J. K. Galbraith)

Once a policy was adopted and implemented, all subsequent activity is transformed into an effort to justify it. (Barbara Tuchman)

Personal note: The reader may find some passion in this paper. As we write, Brazil has lost more than half a million to the pandemic, millions are going hungry, while the President says it is just "a little flu" and mocks those who cry over their loved ones, mimicking a spoiled child crying. Our problem is not having this president but the system that permits such a character to reach the presidency and cause such harm. The government should manage the country's public affairs, not teach us patriotism, how we should pray, or make love. Our aim here is to understand the social and economic workings that permit the worst of us to come to the top. Objectivity in social research does not demand cold neutrality. The arguments have to be solid, but our emotions are just human. This paper is about a dumb system, not just about a dumb president.

\section{THE POLITICS OF AUSTERITY}

A usterity does not work. Capitalism, to expand, needs producers, but it also needs consumers. The central argument for the reversal of the inclusive model in Brazil was that we do not have sufficient resources to include the poor. According to different promoters of the coup, social policies and a decent minimum wage would not fit the economy, the budget or the Constitution. But the numbers are simple: Brazil produced 3.1 trillion dollars of goods and services in 2019 (GDP in Purchasing Power Parity dollars). For a population of 212 million, this amounts to a per capita of US\$15 thousand a year, or US\$5000 a month per four-member family. This means that Brazil produces more than enough to ensure a comfortable and dignified life for everyone if inequality is reduced. The problem is not the lack of resources but rather the absurdity in its distribution. This reasoning can be extended to world figures: the US\$85 trillion global GDP is quite sufficient if reasonably distributed, for at least ensuring we get rid of hunger and other dramas that are making billions suffer. But Brazil, with a Gini of 0,52 , is among the ten most unequal countries in the world. An austerity program for Brazil makes no sense: two-thirds of the population already live in deep austerity, and the wealthiest six families have more wealth than the bottom half of society.

During the Lula Government, economic growth was not only strong, but the income of the poor majority grew faster than that of the rich: everybody gained, the poor proportionately more, which reduced inequality. The poor showing up in society generated the expected reaction from the rich: the same they had with Getúlio Vargas (ousted in 1954), with João Goulart (dismissed in 1964), with Dilma Rousseff (ousted in 2016) and with Lula, who only did not get elected in 2018 because he was imprisoned, two months before the election, on fabricated corruption charges. Distribution does not 
work well with the elites, neither does economic democracy.

It seems Brazil can only have democracy if it is not used. The last inclusion policies worked, but for a short time, from 2003 to 2013. Dark times and violent politics seem to be the rule, and for the oligarchy to see that what works is what they have consistently criticized is unbearable. In Brazil, with an absurd law approved in 2016 prohibiting expansion of public social investment for 20 years, inequality was written into the legal system, changing the 1988 Constitution. The recommended austerity is for the poor who are already deprived and not the rich, which is where the money is. With a stagnating market, even before the pandemic, business was working near $70 \%$ of capacity. With more poverty and stagnating demand, who is the business going to sell to?

\section{A STUPID COUP}

The World Bank called the Brazilian development experience from 2003 to 2013 The Golden Decade. One must be very ideologically blind to ignore the enormous progress represented by unemployment falling from $12 \%$ in 2002 to $4.8 \%$ in 2013, the creation of 18 million formal jobs, the 38 million taken out of poverty, the reduction of the Amazon rainforest destruction from 28 thousand square kilometers in 2002 to 4 thousand in 2010, the access to electricity for 15 million poor and so forth. Strong regular progress for ten years represents the sound policy, not just a temporary lucky set of events, what we in Brazil call a "chicken flight". And it is a trend we must rescue, for we have some 150 million people who still need to improve their access to individual and collective goods and services. This is a huge opportunity to stimulate economic growth, a horizon to reach. Foreign trade may help, but it is not the solution since exports represent only $10 \%$ of our GDP. We are not Asian tigers. The fundamental problems and solutions are internal.

Mental confusion naturally makes it difficult to accept evidence when you want to be convinced of the contrary. This confusion is fed and stimulated by a sophisticated form of organized rubbish we presently call a narrative. We were told that doing what is suitable for the people is populism and that this populism brought our budget down. The image they created and have repeated ceaselessly is that a good housewife only spends what she has. Dilma spent too much, so this housewife must go. The president being a woman was clearly used.

But the numbers are simple: what generated the deficit were not the economic and social policies of the government, but the scorching interest rates on the public and private debt, the so-called financialization. In 2021, we have 62 million adults stalled in debt, unable to pay the interest, not to speak of reducing their debt, and blacklisted by Serasa-Experian. This US-based corporation controls credit information in Brazil. They are 62 million adults in a 212 million inhabitant country, add in the children, and we are speaking of around $40 \%$ of the population. This is not a housewife spending too much; it is the banks earning far too much.

When Dilma tried to reduce interest rates in 2012 and 2013, war was declared on her by the banks, as well as the rent-earning high and upper-middle-class. Just for the 
record, the interest rates she tried to reduce were $44 \%$ average for business, $88 \%$ for private persons, and 14\% for government bonds, while the inflation was around 5\%. This is technically usury. They were bleeding the economy at a very accelerated pace. No economy can work with this kind of interest rate. But depriving the rentiers of this enormous flow of easy money was politically unsustainable. Nothing very new for whoever read Michael Hudson's Killing the Host or the Roosevelt Institute studies on The High Cost of High Finance. High finance is running the show.

They ousted Dilma without a crime, jailed Lula without proof of guilt, and elected a sinister far-right candidate precisely because the candidate who was going to win was put in jail. The judge who had him jailed gained the post of minister of justice. In 2019, Intercept recordings published by Glenn Greenwald gave us a full picture of the conspiracy. The fact is that the judge and the prosecutor worked hand in hand against Lula and his lawyers, and when the Supreme Court thought of intervening, a general cowed it into silence. The whole setup is being exposed in the international press and was criticized by judges throughout the world. The fact is that Lula was a political prisoner. When he left his 8-year of presidency in 2010, his approval rate was $87 \%$. In 2021, Lula was finally cleared of suspicion by the supreme court. The judge who had him jailed was put formally under suspicion himself. Lula is the favourite candidate for the 2022 presidential election.

The political dimension is obviously linked to the financial results. If the new group that organized the coup had been able to maintain the economic growth, things would probably have worked out. But they resorted to the very traditional recipe that had stalled development during the 1990 decade, with Fernando Henrique Cardoso: privatizations, high-interest rates, and environmental and social regulation reduction. In recent years, the economy suffered a $-3.5 \%$ recession in $2015,-3.8 \%$ in 2016 , and has been stalled ever since, with a $1.3 \%$ growth in 2019 and $-4,1 \%$ in 2020 . It is the eighth year they are "fixing" the economy. This is simply not working. And the more they become aware of it, the more they explain the sacrifice was not sufficient.

But the narrative keeps rooted because it is simple and gives the populace someone to blame: Dilma broke the economy. The president being a woman helps the narrative. It is a farce. Deficit during the Lula and Dilma period (2003-2013) was never significant, even including the interest rates on public debt. But for so many people, particularly when they do not understand the process, politics is centred on emotions. The financial system broke the economy but did give people someone to blame, a woman, and a stubborn and outspoken one, the ideal victim. The power of banks works today only for bankers and rent-seekers. In the line of an American quip, we can say our problem is that a minority who earns half a million a month has convinced the groups earning 50 thousand a month that our problem is the guy who makes a thousand reais a month. Narratives work.

Those who are sorry for having helped to break legality in the country are presently called 'widows' of the coup. They opened the doors to the absurdity we presently must cope with. Elementary common sense shows that what works is effective representation, in the line of the first article of our Constitution: "All power stems from the people”. In this fundamental sense, the newly elected government is not legitimate. 
We elected a far-right moron because the legitimate candidate who was going to win was jailed, because the big media created an anti-PT hatred movement, because they organized an industrial-scale fake news campaign, and because a criminal attempt on his life granted him a victim aura, besides saving him from what would have been a humiliating presentation of his political views on TV debates.

It is not a question of accepting or not the result of an election, but understanding that his representation is very limited: imagining we can generate sustainable development based on far-right sectarian political power makes no sense. To survive with a very narrow internal support structure, this group had to seek the support of the Trump administration and foreign corporations, and is opening the doors to predatory national and international interests in the Amazon forest, oils reserves, deregulated agro toxic agriculture and so on. Internally, its survival rests on the promotion of God and homeland and of hate against "the enemy", chosen with anticipation as guilty of the poor results of the government. Hate and violence tend to be the natural road-fellows of elitist policies. Incompetence is always on the lookout for whom to blame. Considering the weight of American policies in Latin America, the Biden election did open a new space for change, but the political mess has grown deep roots, among others changing key principles in the Constitution.

\section{DUMB RENT-SEEKING}

The profit we earn on productive investment is quite legitimate: it generates jobs, goods and services, and pays taxes. On the other hand, profit on speculative investment generates dividends and huge returns without any productive contribution. Bankers call the different papers we can invest in "financial products", and they love to call themselves "financial industry", except they do not generate products and are not industrial-pure cosmetics. Money earned from financial speculation will not put one more pair of shoes on the market. Making the difference between productive investment and financial allocation is basic. No trouble with the distinction in French, "investissements" and "allocations financières", or even in Portuguese, "investimento" and "aplicações financeiras”. But the banks prefer to call everything "investment”.

The British handbook on how money works, edited by Kathryn Hennessy, explains the financial snow-ball effect: financial papers yield roughly between $7 \%$ and $9 \%$ a year during the last decades. Whereas effective production of goods and services, which demands more tiring work, has been growing at an incomparably slower pace, on the order of $2 \%$ do $2.5 \%$ a year. Those who have spare money will obviously put it where it grows better. For example, the owner of 1 billion locating his money in papers paying a modest 5\% a year, is earning 137 thousand dollars a day, without producing anything. And every day, a part of this rent is making the snow-ball bigger, generating non-productive ever-accelerating wealth.

The result is we will have more billionaires while the real economy is deprived of the necessary financial resources. This is capitalism shooting its own foot, slowing down economic growth and reducing its basic legitimacy. In the world financial casino, we have seen the richest $1 \%$ of the planet accumulate more wealth than the remaining 
99\% from crisis to crisis. When speculative investment yields more than productive effort, the process becomes systemically dysfunctional. Obvious and well explained in Thomas Piketty's (2013) studies. And nothing new for finance researchers such as Paul Dembinski and Alain Shoenenberger, who wrote in 1993, 25 years ago: "The financing of production and trade is a matter of purely marginal concern to financial markets. Instead, they are chiefly concerned with managing previously accumulated wealth. It is only a slight exaggeration to state that a society of producers is gradually making way (at least in people's imagination) for a society of interest-earners." We are entering a rentier society.

The market economy was supposed to facilitate exchange between producers and consumers while generating products, employment and income. Nowadays, the "markets", a limited group of speculators, show a surge of optimism whenever the population loses rights. It is the logic of folly. We do not have to go very far to learn something positive: China controls its financial system so that money is productively invested, the Germans rely on their local banks (sparrkassen), ensuring that money is invested in what the community needs, the Nordic countries have decentralized financial systems, just to mention o few. We know what works: it is when money is productively invested.

A practical example may help: a few years ago, South Korea invested public money in a large project of non-polluting public transportation. The investment generated a series of technological innovation and production initiatives, thus creating employment. Since public transportation is energetically and financially much more efficient than filling the cities with cars, the investment was paid back. Pollution was reduced both by the electric engine technology and the reduction of the use of individual transportation. Less pollution in the cities means less money spent on hospitals and other health costs. The reduction of the time lost in transportation means people are less tired and have more time for leisure and improved productivity.

The example only illustrates the obvious, which is that our resources should be invested in projects and programs that have multiplying effects in terms of stimulating the economy, protecting the environment and improving the well-being of families. So much intelligence is wasted searching for more sophisticated financial mechanisms, which could create socially and economically valuable projects. Making society wealthier is what works.

\section{THE INTEGRATED FINANCIAL FLOW}

How does this work in Brazil? The numbers are not difficult to grasp; we just have to put them together. The economy works when you put the money where it multiplies. If we take a loan to buy some kind of equipment, improving productivity. Thus, at a higher rate than the interest rates we have to pay, we can continue buying more equipment, generating more products, employment, and income. But if the cost of credit is higher than the generated income, we will drown in successive loan renegotiations, ending up working for the bank. As Zygmunt Bauman writes, bankers hate good payers. This fundamental deformation hits the main economic actors - families, businesses 
and the state - which become tied to a process of permanently feeding the financial intermediaries. Herein lies the mechanism which generated our economic recession and the ensuing political chaos we are living in. But our leaders seem convinced that the solution is to put more bankers in charge of politics.

Let us get to the numbers. In Brazil, families and businesses spend 1 trillion reais a year just on interest, without reducing the debt, just rolling it over. Considering our GDP in 2019, before the pandemic, was 7.3 trillion reais, we are speaking of $14 \%$ of GDP. This surrealistic amount is simply due to the huge interest rates we pay, technically speaking constituting usury. In May 2021, for example, banking interest rates for families was on average $98.5 \%$, when in France they are below $5 \%$ a year. Thus, the financial system drained the purchasing power of families and the investment capacity of businesses. We have government-controlled much cheaper credit lines, such as the credit automatically paid from salaries (crédito consignado), but this risk-free credit pays bankers around 28\%. Overall, it is an unsustainable financial drain on the productive economy.

The flow of interest on families and legal persons generate earnings for financial intermediaries, which are in significant part invested in public debt papers. Government has to pay interest on this debt, basically to banks, institutional investors and wealthy individuals, over 300 billion reais a year, roughly equivalent to 6\% of GDP, $20 \%$ of the public budget. At about $75 \%$ of GDP, our public debt is not exceptionally high, but has been paying very high interest. Thus, instead of financing infrastructure and public social policies, our taxes end up in the pockets of financial speculators, people who do not produce anything, on the contrary, extract resources that could have been productively invested (cf. Eisinger et al. 2021).

If we put together the $14 \%$ taken from families and businesses and the $6 \%$ they appropriate from our taxes, we speak of $20 \%$ of GDP. A tiny part of this returns to the real economy. In the absence of Brazilian figures, we can imagine less than the $10 \%$ Epstein and Montecino estimated for the US financial flow. This is obviously an unsustainable drain on the productive economy. But the negative impact is amplified by the tax system. While in Europe, the deformation is partly corrected through taxes on financial capital, fortunes, inheritance and high income, in Brazil, the rich pay proportionately much less than the poor, and since 1995 distributed profits and dividends have been exempted. Tax evasion for 2018 was estimated at 620 billion reais, $9 \%$ of GDP (Sinprofaz). Tax on salaries is deducted at the source, and there is no way for the poor to escape indirect taxes, so tax evasion concerns basically the rich. The process is technically supported by banks, which have specialized departments for what they call "tax optimization". The names used in finance are outstanding, such as precisely calling any financial speculation “investment”.

A significant part of tax evasion relies on tax havens, with so many asset management groups located in Panama, Cayman Islands, or Delaware in the US. And we have Switzerland, which, as Jean Ziegler wrote, "lave plus blanc", offers superior laundering. The fact is that the stock of unproductive financial resources in tax havens was estimated at 20 trillion dollars by the Economist, more than a quarter of 2012 world GDP of 73 trillion. According to Tax Justice Network, the Brazilian participation in 
this amount was around 520 billion dollars, which represented roughly $28 \%$ of GDP. Not only do they not invest, but do not pay taxes. With major US corporations using similar strategies, as the ProPublica leaks have shown, it has become mainstream (The Economist 2021).

What we see here is an impressive dimension of financial drains on the economy. But we also have a series of smaller drains, such as the complementary pension funds, which with assets corresponding to around 15\% of Brazilian GDP could obviously be used to invest in economic and social development instead of feeding on financial speculation. It is also the case of the insurance industry, with assets also corresponding to $15 \%$ of GDP (1 trillion reais), in great part located in public debt papers. Rent-seeking is also characteristic in a diversity of sectors, such as private health schemes, communication over-pricing, big pharma patent manipulation, etc.

Our 1988 Constitution stated clearly that "the national financial system will be structured so as to promote the balanced development of the country and to serve the interests of the collectivity." Nowadays, the system is essentially used to channel money to the unproductive, whether bankers, national or international corporations, or the rich who have even managed to demonstrate on the symbolic Paulista Avenue in São Paulo, wearing national colours in support of the far-right government. The truth is that banks have created a system through which our taxes are channelled in great part to unproductive rentiers. The bankers are presently in charge of the government, drain its resources, and proclaim that the reason we are suffering is that the State is too big, taxes too high, and the poor irresponsibly favoured by social policies.

The absurdity of all this? Well, it would be incomparably more productive for all of us and quite comfortable for banks if they provided funds for the economy instead of draining it. China reached this development capacity because they channel financial resources to productive use. In our case, short term greedy attitudes consisting in playing around with financial papers, or having money grow in tax havens, generated the 2015 and 2016 recession and kept the economy stalled, even before the pandemic. How come we study in detail the productivity of every hectare in agriculture, or the productivity of each industrial worker, but never have a look at the social productivity of financial resources?

\section{THE DUMBNESS OF INEQUALITY}

Maintaining this degree of inequality is particularly absurd, but it is central in the present administration policy (Global Multidimensional Poverty Index 2019). After all, the wealthy groups in power defend their interests, and we seldom have anyone in powerful positions who is not rich, white, man, and concentrated on improving his already impressive advantages. The question is, of course, that from a certain level of inequality and divorce between access to wealth and productive contribution, the system tends to become dysfunctional. Merit should play a role, even for the happy few. They threw the economy into recession, unemployment and political chaos. Who is this working for?

Does it work for the rich? Raising families in absurd closed condominiums, or in 
mansions where they have to cope with in-house security teams, protect themselves in armoured vehicles, hiding their fortunes in tax havens, managing tax evasion schemes, and finding comfort and relaxing in developed countries - civilization at last - all this has little in common with a society where you breathe freely. Innumerous international comparative studies on quality of life perception show a radical quality of life improvement is when a poor person has access to a decent income but practically does not improve when a millionaire gets more millions. Not even for them does this system work. If we are to improve our overall feeling of happiness, there is no doubt that inclusion policies work better for everyone. When more money flows to the bottom of the social pyramid, we generate more happiness and more economic activity. Reducing inequality has strong impacts in ethical terms, as well as political and economic ones.

In ethical terms, it is difficult to find words that would be strong enough. In no civilized society could a person have no access to basic health services, a child or an adult have no food, families without shelter or spending years in refugee camps. Multidimensional poverty now hits 1.3 billion people, of which 663 million children and 428 million under ten years of age. (UNDP/OPHI) Is this poverty their fault? Lack of initiative? We must stop the "bullshit"; the rich, not the poor, created this absurdity. Almost a billion people and growing are going hungry, while we produce more than one kilo of grain per person per day, and a third of the food we produce is lost by mismanagement.

All these irresponsibly rich drain our resources for ostensive consumerism or financial speculation instead of helping to implement policies that work for the whole of society. These corporations generate social, economic and environmental tragedies, navigate proclaiming values no primate would accept (greed is good), and whose ethics consist in grabbing a more significant piece, no matter the suffering, damn the planet. What we have here is impressive intelligence in getting to the means and stunning idiocy in defining the ends. Should we build taller walls to contain the poor, organize more cocoons for the rich, develop more violent and constraining repression systems? The poor do not deserve their poverty, neither the rich deserve their wealth.

This inequality is evidently also dysfunctional in social and political terms. From a certain level of inequality, there is no room for social solidarity or democratic conviviality. Violence tends to contaminate all domains. In the US, people buy more guns. In Brazil, the army invades favelas, and the police kill an average of 16 persons a day. Well, we have no death penalty in Brazil. Europeans do not know what more to invent to protect themselves from migrants fleeing the colonies Europe had so violently exploited. We are not speaking of perfect equality here, but of a little less obscene scenario, where every person could be valued as a human being and have opportunities to thrive and contribute. Reality is straightforward here: when people are placed in desperate situations, they react desperately. There is a limit to good behaviour by millions who find all the doors closed. We have the resources, we have the technology, we know what has to be done, and it costs very little. The 2030 Agenda is here for everyone to see. Is it an exaggeration to speak of ignorance? We find ourselves institutionally helpless.

And inequality is particularly dumb from the economic point of view. We all know 
how the New Deal worked in the US, how the Welfare State brought prosperity to so many presently rich countries; we have all the data on the South Korean miracle, of the impressive rhythm of development in China, of the Golden Decade 2003-2013 in Brazil. All these experiences have in common the expansion of purchasing power of the population in general, access to universal free public social policies, all of which stimulates production and employment. Productive entrepreneurs do not need Chicago Boys economic ideology, they need people with purchasing power for their products and cheap credit to invest. Brazil has neither.

The mechanism has been well known since almost a century ago, with Kalecki and Keynes. But it is basically common sense. Investing in the population's well-being stimulates demand, generating more production and ensuring more jobs that create more demand. Family consumption and business production generate more taxes which puts back into government whatever was spent to stimulate the inclusion programs. And a population with access to social policies, with more health and education, is simply more productive, besides being more satisfied with life. Here we do not need ideology and hatred or scapegoats, but a simple look at the experiences that have worked and are working today in many places. What works in economics is when the economy is directly oriented according to the priorities of family wellbeing. Inequality, in economic terms, only maintains a narrow space of activity and low social productivity.

Let us put a conditionality in this reasoning. I worked for seven years in Africa in impoverished countries. Just spreading money will not work if you do not have the corresponding productive capacity. In these conditions, you have to balance productive investment and consumption support. But in the case of Brazil, where businesses are working with $70 \%$ of capacity, distribution does not generate inflation, as was clearly seen in the 2003-2013 distributive phase. And the poor have a simple consumption profile, goods and services which can easily be expanded. What inflation we have in Brazil does not result from excessive demand but from traders' speculation. What works for productive companies is people with money to buy what they produce, and cheap credit to finance investment. In Brazil, they have neither.

Maintaining and reproducing inequality, when it disorganizes our societies in ethical, political and economic terms, is profoundly dumb. As we are doing throughout the world, increasing inequality, but particularly in the US and Brazil, is in the sphere of pathology. All the positive examples we have, from Canada to South Korea, in Germany and Nordic Countries, and of course in China, are based on expanding internal market and social policies instead of generating privilege for the few. The promotion of the Global Green New Deal, the first steps towards ESGs (Environment, Social and Governance) are no more than the first steps, but point to a growing consciousness of the slow-motion catastrophe we are heading to.

\section{THE STATE, BUSINESS AND CIVIL SOCIETY}

At the centre of our challenges is the necessity of redefining our institutions to implement policies that make sense. New Rules for the 21st Century, the Roosevelt Institute 
called it. Change the Rules is the title of a New Economics Foundation report. The debate over politics has mainly been centred on the war between those who want to privatize and those who have a more active government. The reality is that we presently are too complex societies for this kind of simplifications to work. Effective policies are based on a reasonably balanced intervention of the state, business, and civil society where they work. Corporations without public interest restrictions turn to the mafia, the state without public control tends to become authoritarian, while public interest without civil society organizations strong enough to face both corporations and the condition tends to be over-run. There is no political Santa Claus.

But it is not complicated. The overall objective is sustainable development, balancing economic, social and environmental interests. Nowadays, the 17 goals and 169 objectives of the 2030 Agenda clearly describe where we should be headed: ensuring decent life for all without screwing the next generations. And we know what works: it consists in orienting the complete economic cycle towards the well-being of families. This, after all, is what we mean when we speak of economic and socially sustainable development. It certainly depends on our direct income, the pocket money we earn, which allows us to pay our bills. Ensuring a reasonable income for all consumers will, in turn generate demand, stimulating productive activities. Both direct consumer activity and business production generate taxes for the public dimension of development.

The government will in turn, be able to use these resources to what has been called indirect salary, which allows us to have access to collective consumer goods and services such as health, education, culture, security, a clean river, parks in the city, energy and transportation infrastructures and the like. Access to collective consumption is fundamental. It is much cheaper and much more efficient to have free public universal access to health services, such as in Canada than facing the dominantly privatized American out-of-pocket system. The numbers are glaring: American costs 10,400 dollars a year on health services, while the Canadian system, costing 4,400 dollars per capita, presents much better final results. Not to speak of the reduction of anxiety when you live in a country where you know you will not be unable to pay a doctor for your kid (cf. Abernathy et al. 2019).

Public, universal and free access to some basic social services is simply more efficient and hugely important for reducing people's stress, one of our chief social scourges. It is ridiculous to call public social investment "expenditures" when we are speaking of the most efficient way of ensuring access to essential public consumption services. Strangely we put names on things, and the papers bankers push us to purchase are called "financial products" and "investments". At the same time, health and education are classified as "costs" or "expenditures" when they constitute very efficient investments in human capital.

The dumb attitude here consists in maintaining an ideological war between pro- or anti-state attitudes, when it is natural that individual consumption goods be managed in the private sector, social policies and infrastructures in the public realm, and vigorous civil society organizations insure the trade-off and coordination between both areas. Democracy limited to a vote every few years is fake democracy. Instead of stupid 
macho declarations against the "nanny-state" and other idiocies, we need common sense and a good look at countries where things are working.

\section{AN INFORMED SOCIETY}

We learned from Jung that thinking is a laborious activity, so people would rather have opinions. We obviously have a right to our thoughts, not to our facts, but it seems not to matter very much. What is impressive is that we have so uninformed a society when we are awash in means of communication, at home, in the street, in any waiting room, in our pocket. In good part, if we must choose between facts that reach our brain and the opinions which get our guts, we clearly prefer to be in peace with our guts. We rationally select the facts or deform them to justify what we want to believe. Demagogues worldwide, nowadays organized in the consensus-building industry Noam Chomsky has presented so well, have learned that mobilizing people through hate is much more efficient than explaining complex reality. When presenting a culprit, hate generates a powerful popular catharsis, an immense excitement of belonging to a punitive gang: KKK and the black, Hitler and the Jews, Palestinians in Israel, China in the US (Fidel and Hussein are gone), immigrants in Europe. In Brazil, we have even reinvented communism to justify Lula's hate and the poor in general.

Kurt Anderson (2017) writes that the United States suffered a mutation that transformed the country into a Fantasyland: "Among the one billion websites, believers in anything and everything can find thousands of fellow fantasists, who share their beliefs, with collages of facts and "facts" to back them up. Before the internet, crackpots were mostly isolated and surely had a harder time remaining convinced of their alternate realities. Now their devoutly believed opinions are all over the airwaves and the Web, just like actual news. Now all fantasies look real."

Political demagogues with their hate speech or flattering patriotism, corporations that convince us we are more important if we pay 300 dollars for a Montblanc fountain pen (it writes), Think Tanks that are mushrooming everywhere - from the giants financed by the Koch brothers to our modest Millenium imitation in Brazil - oil and coal giants funding fake science to convince us that climate change is fake science, all these points not only to the fact that we are very fragile in terms of how we use reason, but that we have a gigantic planetary opinion building industry to make a profit on it. Noam Chomsky spreads the vaccine against this deformation.

From 2013 on, the Globo communications empire orchestrated an impressive anti-corruption theatre, a show every night featuring the last corrupto, suggesting the hidden links to Lula. A fake news industry, managed by marketing corporations, created the deep political polarization we presently know to have been very similar to what was organized for Brexit or Trump. The Brazilian novelas became politics. Instead of information, we now have 'narratives' and huge manipulation industry.

Our brain becomes an instrument to invent reasons to believe in what has no rational basis whatsoever. In a context of huge information overload, having such an uninformed society points to the particularly dumb way we organize access to knowledge. We have made a technological information revolution and use it to create fake 
reality.

\section{THE TECHNOLOGY PARADOX}

It is impressive that we have to worry about the advance in technology. After all, being able to do more with less effort should make us glad. We improve social productivity. But the explosive technological change we are living in demands innovative forms of regulation and social organization. In the grab-all world, we curiously call neoliberalism, the new technologies lead us to transform climate, destroying our forests, drastically reducing biodiversity - all on unprecedented scales, precisely because of the power of technologies. The expanded creativity new technologies permit become dangerous when we have such difficulty in coping with systemic change. Wating for the markets to solve the structural challenges will not work. The research by Wallace-Wells, The Uninhabitable Earth, helps in understanding how deep this goes.

And we also have an impressive difficulty in looking at the long term. It is remarkable that the 2008 crisis seems like yesterday, while 2030, an equal distance in years, seems lost in the future. Not to speak of distant 2050 or mythical 2100. And yet, my newly born grand-child Leonardo will be 31 in 2050, and in 2100 will have the professor's age who is writing these lines. The future is right ahead and coming fast. We are living a slow-motion catastrophe, reading our future in scientific research papers as in the last pages of One Hundred Years of Solitude.

It is obviously a question of radically improved governance. Why should we worry so much about technological unemployment when improved productivity means we could work less and dedicate more time of our lives to culture, leisure and conviviality? We can better organize our working schedules, let the economy expand in areas that will allow us to enjoy our lives better, and ensure universal basic income so that no one is reduced to a desperate situation in the transition. But most of all, we must generate regulation and governance capabilities so that we do not destroy our planet. The Brazilian government has opened a free-for-all policy concerning the destruction of the Amazon forest, even producing an impressive propaganda documentary on how we must claim the right to exploit our resources. And our minister of foreign affairs attributed the climate challenge to a "Marxist conspiracy". Fortunately, he did get kicked out, and governments changed, but there is a mismatch between the amplitude of necessary measures and the shallowness of governance reach (Belluzzo\& Bastos 2016).

In other words, looking at the expanding technological capacity, we have to ensure it is used for economically sound, but also socially just and environmentally sustainable development. The free-for-all battlefield we generously call 'markets', inherited from the $\mathrm{XX}^{\mathrm{o}}$ century, but with $\mathrm{XXI}^{\circ}$ century technologies, is a disaster. Using so much technology and knowledge to deepen the environmental, social and economic crisis, frankly, is systemic folly. 


\section{COMPETITION OR COLLABORATION}

We know collaboration works. But instead, we wage war among all of us, between social groups, religions, countries, corporations, neighbours. In a great measure, obviously, it belongs to our nature. Chimpanzees are different from bonobos, and so are we. Reading Our Inner Ape by Frans de Waal (2005) is inspiring. But the essential thing is that we can see, in so many examples throughout the world, that it is also a matter of institutions. It was not in the nature of the German to kill people in concentration camps, nor is it the case with American frontier guards tearing children apart from their mothers. And we can see how societies much more centred on collaboration, like Canada or the Nordic countries, are prospering not only in terms of quality of life but also of economic productivity. And persons forget, when they look at the impressive rhythm of transformation in China, Vietnam or other "tigers", at what point this is anchored in their collaborative traditions built on the rice planting culture, where the water resources must be shared, where transplanting is a collective culture, with chanting and all.

What is essential in this short life of ours is not only the result but also the process. Transforming life into hell and then showing increased productivity leads us to think, after all, what is it we want? Life is the walk itself, and turning the path less thorny can be more important than getting there faster. People are rediscovering the common good through access to knowledge, a protected environment, infrastructures that generate a more comfortable life, as well as harmonious links between the different types of activities. With world urbanization, many cities are taking over through local governance, seeking more balanced development, organizing collaboration between the various economic and social stakeholders. With evolution towards a knowledge society, we are discovering the obvious, that ideas can be freely shared without additional costs, in the framework of the zero-marginal cost society so well described by Jeremy Rifkin (2014). With planetary connectivity, we have a new immense sphere of collaboration opening, something Hazel Henderson has shown so well in her Building a Win-Win World.

It is high time we get a little more civilized. A simple verse by a Pernambuco famous poet is full of wisdom: "Where at are we all rushing to, why so much greed if nobody came here to stay?” Frankly, all those super executives, whether politicians, entrepreneurs or religious leaders, get us tired. We prefer the peace of everyday life, the pleasure of social exchanges, the joys of conviviality. And we have all the science and wealth necessary to ensure well-being for all without so much ideology of individual success. It is good to succeed, of course, but not by only rushing through life, pushing people around, creating human and environmental dramas, even killing people as is happening in so many regions. When the rules become flexible and the laws adjustable to the strongest, we all become anxious or insecure. And fear generates hate. Is this necessary? Until when will we accept the stupidity of selling more arms to more people in the name of making them feel safe, a Trump policy also promoted in Brazil? Of sending the army to favelas instead of facing the absurdity of their existence? Is it demanding too much from intelligence to understand that it is more productive to act 
upon the causes than the consequences?

\section{LAW AS A VECTOR OF INJUSTICE}

Legality is fundamental. The set of laws defines the rules of the game in society. And equality in the face of the law is essential, allowing us to feel secure in our lives. A central problem, of course, is the question of who makes the laws. In the really-existing society, laws are made by men and not coincidentally white and rich. And, as could be expected, they tend to privilege men, white and rich. There was a time it was legal for a person to buy another person as a slave. Lincoln, as president, managed to change this law through a series of legally questionable initiatives. It has been commented that a profoundly ethical person attained the most outstanding humanitarian progress in the United States through some dishonest means. In Brazil, the habit of legislating in one's own interest leads us to chaos, eroding the legitimacy of law and even the judiciary system.

Our recent legal transformations are very significant. We can say the Constitution of 1988 , the way it was negotiated, was legitimate. But within this legal framework, deeper power structures have transformed it into a Frankenstein. Follow the process. The new Constitution was enacted in 1988, after years of military dictatorship, reaching a certain level of civilized governance. But in 1995, congress approved a law that opened the gates to rent on public debt: as of July 1996, banks would be able to invest our money in public debt bonds, paying an astounding $25 \%$, already with low inflation. Regular earnings on public debt are usually in the $0.5 \%$ to $2 \%$ a year bracket. It was called the Selic rate and was, as it continues to be, a present to bankers. This is a legal form of taking over public money. Well, the law is the same for everybody, so the poor, if they had money, could also profit from the opportunity. The fortunes thus earned by the wealthy were also exempted from taxes: in a Christmas present on the $26^{\text {th }}$ of December 1995, distributed profits and dividends would not pay taxes. The bank employees pay their taxes already deducted from their salaries, but the millions going into bankers' pockets are exempt. This is one more Brazilian originality. And it is in the law.

There is more. In 1997 government sanctioned a law authorizing legal persons to finance political candidates. With this corporate funding of elections, public administration became a prisoner to the major clusters of economic power, such as the agri-business, leading banks, etc. It took 18 years, at the end of 2015, for the Supreme Court, guardian of our constitution, to notice that the first article, which states that 'all power stems from the people', not the corporations, had been violated. But these 18 years were sufficient to profoundly change the political landscape. In 2003 Congress elected with corporate money eliminated article $192^{\circ}$ from the Constitution, and interest rates, which had been limited to $12 \%$ plus inflation, were now free to reach usury level. Financial regulation ceased to exist.

Lula was perfectly aware of the power balance in the country and read, in June 2002, what was called a Letter to Brazilians, which could easily have been called a letter to bankers: he would not mess with their interests. In fact, with the elimination of Article 
$192^{\circ}$ that had drawn up the legal framework of the national financial system, he would anyway have the little legal capacity to regulate private banking activity. Despite the economy bleeding with the excessive interest rates, impressive results were attained, as we have seen.

But in 2012, with more than 50 million adults unable to pay their debts, businesses facing reduced demand and high-interest rates, and government hampered by the public debt drain, Dilma decided to reduce the financial drain, mainly using public banks and the official public debt rate, by lowering interest rates. This drastically reduced the vast financial profits made by banks, institutional investors and the higher-middle-class. She did not have the strength to face the political backlash. We know what followed: boycott, street movements, and the coup. Formally Dilma was ousted in 2016, but in fact, from mid-2013 on, there is no government, just chaos. Guido Mantega, the competent finance minister of Dilma before the impeachment process, clearly shows how both internal and international financial interests brought the distributive system down.

Vice-president Temer, who actively supported the coup, became President and changed the Constitution so that social policies would freeze for 20 years, and raised the interest rates on the public debt again. In mid-2021, as we write this paper, public debt service has exploded, while in the private sector, 62 million adults are unable to pay their debts. Average personal credit interest rates in June 2021 are $74.72 \%$ in commerce, 288.35 for credit card revolving credit, $132.91 \%$ for overdraft, $48.33 \%$ for personal bank credit. Inflation is roughly $5 \%$.

Moral of this sport: speaking of legality became a make-belief exercise. In a small book in 2015, Os Estranhos Caminhos do nosso Dinheiro, the strange paths our money follows, we describe how large-scale corruption creates its own legality. A corporation paying a politician to vote for a particular law is a case of corruption. But between 1997 and 2015, paying a politician to get elected, thus having his votes in the corporation's pocket for four years, was declared legal, much as the system created in the US in 2010. You only are forbidden to purchase a politician in retail operations. In the US, they say, "we have the best congress money can buy".

We do have a basic legal framework, what remains of the 1988 Constitution. And a guardian to make it respected, the Supreme Court. But by abandoning legality and supporting the coup, giving an appearance of "legal process" to right-wing putschists, the judiciary facilitated a radical shift to the right. It opened the way to the dramas we presently face, with radical reduction of democratic space. Can anyone trust our politicized judiciary system? They managed a profound demoralization, and the loss of confidence in justice represents a massive loss of institutional capacity in the country. We are facing the absurdity of the judiciary demoralizing justice. The costs for the country are immense and much more than only financial (Warren 2016).

$$
* * *
$$

We are back to the fundamental problem, our impressive difficulty in governing ourselves with a minimum of good sense. For so many people, political options continue 
being defined much more by our guts than by brains, with hatred having more space than solidarity and compassion. In fact, the aggressiveness of groups and social classes that, for some reason, have become powerful seems to be a permanent part of our history, with systematic use of extreme forms of discrimination and violence. Any motive will do, whether skin color, gender, sexual option, religion, income difference, and frequently even age. At times the length of your hair, a beard, or a veil is sufficient to feed the latent beast within us. And when bestiality can find a collective expression and dresses up in moral superiority, it becomes powerful.

Nowadays, the communication system leads to our consciousness being invaded by the most absurd narratives, but usually favourable to dominant groups. Invading our intimacy is presently made possible on the individual level. The control of what we see and interpret allows algorithms to manage public opinion on an industrial scale, as documented in The Age of Surveillance Capitalism by Shoshana Zuboff (2019). Complex financial systems make us lose control over economic activities, generating excessive inequality in favour of unproductive rentiers. Giant corporations distribute their power over the planet, a power no one voted for and not limited by any global governance. And we are rushing, in historical terms, towards the destruction of life on the planet. The Uninhabitable Earth, by David Wallace-Wells, presents as we have seen an excellent overview of these bleak perspectives.

We do have strategic visions, and they are reasonably obvious: rescuing the public dimension of the state, taxing unproductive capital and more generally adapting our tax system to the new economic realities, generating transparency on financial flows, some kind of basic universal income, reduction of working hours according to productivity gains, rescuing the role of cities as fundamental units of bottom-up public governance, and obviously creating a minimum of international governance in the face of the global chaos, as well as democratizing media so that we can have an informed society. Is this viable? The question is not of viability, but of understanding, first, the essentially political dimension of our challenges, the centrality of the question of power. And we must understand that it is a question of time, for with climate change, destruction of biodiversity, the deepening gap between rich and poor, worldwide contamination of water and other growing challenges, we are just using a universal political "mañana", probably until a planetary catastrophe generates the necessary political will. It will probably demand more than Covid-19.

The erosion of what little democracy we had in Brazil can be seen as a burlesque tragedy. We brought down policies that were working; we tore down a Constitution which was protecting us from absurdities. We elected a weak far-right demagogue with very limited political support and who can only survive by letting the oligarchy and international interests free to promote destructive policies. The man in charge of the economy, Paulo Guedes, is co-founder of BTG Pactual bank, which has 38 affiliates in the Cayman Islands, Bermudas, Panama, Delaware and other tax havens. Tax havens are used essentially for financial speculation, tax evasion and money laundering. Is this what we need? How come such a guy becomes minister of the economy?

We do have a kind of deep conscience in Brazil, a mass of common sense in the heads of millions, that would allow us to get back on a constructive road. But we are 
so stiffly divided into left and right. This is comfortable for the right, in that grabbing more resources for the already rich and destroying the environment can be presented as a legitimate political option, an appearance of legitimacy, a question of “opinions”. In fact, the great divide is between those who seek a democratic and sustainable society and those who try to grab more, in the short term, no matter what happens to society and nature. It is not a question of right and left. It is a question of elementary human decency. How long will we tolerate having 850 million going hungry in a world awash in food? And watching on TV as a band of "idiots" in Wall Street justifies anything, chanting "Greed is Good"?

Paulo Freire once declared he wanted "a less evil society”. It seems childish. But our challenges are immense, and we, as teachers, communicators or social organizers, or simple citizens, must face the task of explaining the obvious: a society that works has to be a society that works for everyone. Dumbness should be confronted, or faced, with what works, and that is a society organized for the common good.

FUNDING: This research received no external funding.

CONFLICT OF INTEREST: The author declares no conflict of interest.

\section{REFERENCES}

Abernathy, Nell, Darrick Hamilton, \& Julie M. Morgan. 2019. New Rules for the 21st Century: Corporate Power, Public Power, and the Future of the American Economy. New York: The Roosevelt Institute. Retrieved May 30, 2021 (https://rooseveltinstitute.org/wp-content/uploads/2020/07/RI_2021-Report_201904.pdf).

Andersen, Kurt. 2017. Fantasyland: how America went haywire. New York: Random House.

ANEFAC - Associação Nacional de Executivos de Finanças, Administração e Contábeis

- Pesquisa de Juros. Retrieved May 30, 2021 (https://www.anefac.org/pesquisa-de-juros).

Belluzzo, Luiz Gonzaga de Mello \& Pedro Zahlut Bastos, eds. 2016. Austeridade para quem? São Paulo: Carta Maior e Friedrich Ebert Stiftung. http://cartamaior. com/_a/docs/2016/02/15.pdf

Campello, Teresa \& e Pablo Gentili. 2017. Faces da desigualdade no Brasil: Um olhar sobre os que ficam para trás. Brasil: CLACSO. http://209.177.156.169/libros/Faces_da_desigualdade_no_brasil.pdf

De Waal, Frans. 2005. Our Inner Ape. New York: Riverhead Books.

Dembinski, Paul \& Alain Shoenenberger. 1993. Financial Markets: Impossible mission? Lausanne: FPH. Retrieved May 30, 2021 (http://dowbor.org/blog/wp-content/uploads/2019/07/19-1993-Dembinski-Financial-markets.pdf).

Dowbor, Ladislau. 2019. The Age of Unproductive Capital. Cambridge: Cambridge Schol- 
ars.

The Economist. 2021. “Twilight of Tax Havens.” The Economist, June 1, 2021. Retrieved May 30, 2021 (https://www.economist.com/finance-and-economics/2021/06/01/ twilight-of-the-tax-haven).

Eisinger, Jesse, Jeff Ernsthausen, \& Paul Kiel. 2021. "Secret IRS Files: Trove of Never-Before-Seen Records Reveal How the Wealthiest Avoid Income Tax.” ProPublica, June 2021. Retrieved May 30, 2021 (https://www.propublica.org/article/the-secret-irs-files-trove-of-never-before-seen-records-reveal-how-the-wealthiestavoid-income-tax).

Epstein, Gerald \& Juan Antonio Montecino. 2016. Overcharged: The high cost of high finance. New York: The Roosevelt Institute. Retrieved May 30, 2021 (https://rooseveltinstitute.org/wp-content/uploads/2016/07/RI-Overcharged-201606.pdf).

Fagnani, Eduardo. 2017. “O 'deficit' da Previdência e uma posverdade.” CartaCapital, March 17, 2017. Retrieved May 30, 2021 (https://www.cartacapital.com.br/politica/eduardo-fagnani-o-deficit-da-previdencia-e-uma-pos-verdade).

Global Multidimensional Poverty Index. 2019. Illuminating Inequalities. United Nations Development Programme \& Oxford Poverty and Human Development Intiative. Retrieved May 30, 2021 (http://hdr.undp.org/sites/default/files/mpi_2019_publication.pdf).

Greenwald, Glenn. 2019. “Como e por que o intercept esta publicando chats privados sobre a lava jato e Sergio Moro.” The Intercept Brasil, June 9, 2019. Retrieved May 30, 2021 (https://theintercept.com/2019/06/09/editorial-chats-telegram-lava-jato-moro/).

Henderson, Hazel. 1992. Building a Win-Win World. San Francisco: Berrett-Koehler.

Hennessy, Kathryn. 2017. How money works: The facts visually explained. London: Penguin Random House.

Hudson, Michael. 2015. Killing the Host: How financial parasites and debt destroy the global economy. Baskerville: Islet.

Lacerda, Antônio Correia de. 2016. “Políticas macroeconômicas para o desenvolvimento brasileiro.” Pp. 91-111 in O Futuro do Desenvolvimento, edited by H. M. M. Lastres et al. Brasilia: UNICAMP.

Mantega, Guido. 2021. "Conspiração internacional para derrubar o PT começou em 2012.” Brasil247, July 25, 2021. Retrieved May 30, 2021 (https://www. brasil247.com/brasil/conspiracao-internacional-para-derrubar-o-pt-comecou-em-2012-diz-guido-mantega?amp).

OXFAM. 2017. Uma economia para os 99\%. Resumo executivo em português, janeiro de 2017. Retrieved May 30, 2021 (http://dowbor.org/2017/01/oxfam-uma-economia-para-os-99-2016-relatorio-10p.html/).

OXFAM. 2017b. A distância que nos une: um retrato da desigualdade brasileira. Oxfam Brasil, setembro 2017. Retrieved May 30, 2021 (www.oxfam.org.br).

Piketty, Thomas. 2013. Le capital au XXI siècle. Paris : Seuil.

Rifkin, Jeremy. 2014. The Zero Marginal Cost Society. New York: Palgrave McMillan. (http://digamo.free.fr/rifkin14.pdf).

Sachs, Ignacy. 2014. Desenvolvimento, inovação e sustentabilidade: contribuições de Ig- 
nacy Sachs - Collection organized by Editora Garamond Universitária, Rio de Janeiro, 2014

Tuchman, Barbara. 2014. The March of Folly. New York: Random House.

Wallace-Wells, David. 2019. The Uninhabitable Earth: life after warming. New York: Tim Duggan Books (Penguin).

Warren, Elizabeth. 2016. "Rigged Justice.” New York Times, Jan. 29, 2016. Retrieved May 30, 2021 (http://www.warren.senate.gov/files/documents/Rigged_Justice_2016. pdf).

World Bank. 2016. Brazil: Systematic Country Diagnostic. Retaking the Path to Inclusion, Growth and Sustainability, May 6, 2016. Retrieved May 30, 2021 (http://documents.worldbank.org/curated/en/180351467995438283/pdf/101431-REVISEDSCD-Brazil-SCD-Final-version-May-6-2016.pdf).

Zuboff, Shoshana. 2019. The Age of Surveillance Capitalism. New York: Hachette.

\section{BIOGRAPHICAL NOTE}

Ladislau Dowbor teaches economics at the Pontifical Catholic University of São Paulo, and works as a consultant for different UN agencies, governments and NGOs. His numerous publications and technical studies can be found on his website http://dowbor.org, free of charge (Creative Commons). A detailed account of what we present in the above paper can be found in a recent book, The Age of Unproductive Capital, Cambridge Scholars, 2019, as well as in Beyond Capitalism: new social architectures, Cambridge Scholars, 2021.

OPEN ACCESS: This article is distributed under the terms of the Creative Commons Attribution Non-commercial License (CC BY-NC 4.0) which permits any non-commercial use, and reproduction in any medium, provided the original author(s) and source are credited.

ARTICLE HISTORY: Received 2021-06-25 / Accepted 2021-09-15 